\title{
TRUMP \\ How did he happen and what will he do
}

\section{Richard Lachmann}

State University of New York at Albany, United States of America

\begin{abstract}
This article identifies the long-term bases of Republican electoral dominance. It then highlights the specific factors that allowed Trump to win in 2016. Third, it enumerates the policies that Trump and Congressional Republicans will be able to implement because they control the Federal government. Finally, it discusses the opportunities for opposition to Trump and speculates on the likelihood that those efforts will be successful and how unanticipated events might strengthen or undermine Republican power.
\end{abstract}

Keywords: election, economy, policy, Trump.

Resumo Este artigo identifica as bases a longo prazo do domínio eleitoral republicano. Destacam-se de seguida os fatores específicos que permitiram a Trump ganhar em 2016. Em terceiro lugar, enumeram-se as políticas que Trump e os republicanos do Congresso poderão implementar porque controlam o governo federal. Finalmente, discutem-se as oportunidades de oposição a Trump e especula-se sobre as probabilidades de sucesso desses esforços e como eventos inesperados podem fortalecer ou prejudicar o poder republicano.

Palavras-chave: eleição, economia, política, Trump.

Résumé Cet article identifie les bases à long terme de la domination électorale républicaine. Il souligne ensuite les facteurs spécifiques qui ont permis à Trump de gagner en 2016, avant d'énumérer les politiques que Trump et les républicains du Congrès pourront mettre en œuvre parce qu'ils contrôlent le gouvernement fédéral. Enfin, il aborde les opportunités d'opposition à Trump et spécule sur les chances de réussite de ces efforts et sur la façon dont certains événements imprévus peuvent renforcer ou affaiblir le pouvoir républicain.

Mots-clés: élection, économie, politique, Trump.

Resumen Este artículo identifica las bases a largo plazo del dominio electoral republicano. Enseguida, se destacan los factores específicos que permitieron a Trump ganar en 2016. En tercer lugar, se enumeran las políticas que Trump y los republicanos del Congreso podrán implementar porque controlan el gobierno federal. Finalmente, se discuten las oportunidades de oposición a Trump y se especula sobre las probabilidades de éxito de esos esfuerzos y cómo es que eventos inesperados pueden fortalecer o perjudicar el poder republicano.

Palabras-clave: Elección, economía, política, Trump.

Donald Trump's election victory was a surprise to most analysts who doubted even the possibility that he could win until he actually did. Typical was Sam Wang, a Princeton professor of neuroscience, who as head of the Princeton Election Consortium announced the day before the election a "win probability for Clinton... in the $98-99 \%$ range" (http://election.princeton.edu/2016/11/06/is-99-a-reasonable-probability/\#more-18522). I too did not think Trump could win. The error Wang, I, and almost everyone else made was to focus our attention on Trump himself rather than on his status as the Republican Party nominee. Our assumption was that a man so obviously unfit to serve as president could not win. That blinded us to the reality that it is rare for one of the two parties to hold the presidency for more than two consecutive terms. The last time that happened was when the first Bush succeeded Reagan in 1988. The previous 
occurrence was when Franklin Roosevelt and Harry Truman won five consecutive elections from 1932 to 1948.

Trump's victory was, for the most part, that of the Republican Party, which held its majorities in Congress and fully controls 32 of the 50 state governments. The questions we need to ask are: How did a Republican Party, whose policy positions are rejected by large majorities of Americans, become dominant and how did that dominance extend to someone like Trump? Even more important, we need to figure out how the electoral base that Trump and other Republicans depend on will shape what they do with their control of the US government for the next four years. This article begins by identifying the long-term bases of Republican electoral dominance. I then highlight the specific factors that allowed Trump to win in 2016. Third, I enumerate the policies that Trump and Congressional Republicans will be able to implement because they control the Federal government. Finally, I discuss the opportunities for opposition to Trump and speculate on the likelihood that those efforts will be successful and how unanticipated events might strengthen or undermine Republican power.

\section{Building Republican electoral strength, 1946-2016}

In the thirty-six years from 1932 to 1968 the Republicans held the presidency for just eight years. In the last forty-eight years (1968 to 2016) Republicans were president for twenty-eight of those years. The shift in Congress is even more dramatic. The Democrats controlled both the House and Senate for forty-four of the forty-eight years from 1932 to 1980 (1947-48 and 1953-54 were the exceptions). The Democrats controlled the House until 1994- a run of fifty-six out of sixty years. From 1980 to 2016, the Republicans and Democrats have each controlled the Senate for eighteen years. Republicans have controlled the House for eighteen of the twenty-two years from 1992 to 2016.

Republican control has enormous policy effects, which I will discuss later, but now let us look at how Republican power has had compounding political effects. Elections in the US are privately financed. While some money, especially at the presidential level, comes from ideologically committed small donors, a vast majority of the money spent in Congressional races comes from corporate interests. Capitalists view political spending as a business expense. They give money to gain access to officials so that they can lobby for legislation that favors their interests and also to get members of Congress to pressure executive agencies to change labor, environmental, consumer, health and safety, and other regulations to reduce corporations' compliance costs. Business donors are practical; they give money to the likely winners and those most often are incumbents. Thus, up to 1980 Democrats got the majority of corporate contributions, not because donors preferred Democratic policies (they did not), but because they assumed Democrats would remain in power and that they needed to pay for access to prevent legislation and regulations that would be even more unfavorable to their interests. When Republicans became the majority of incumbents in the 1980s, 
contributions shifted away from Democrats. Republicans have maintained this money advantage ever since.

In addition to gaining money, Republicans have gained the allegiance of racists as Democrats abandoned their alliance with Southern segregationists and took real if half-hearted steps to enforce civil rights for African Americans. A first sign of that shift came in 1946. Hooks and McQueen (2010) find that the Congressional districts that the Republicans picked up in 1946, and which provided them with their short-lived majority, were the sites of aircraft manufacturing plants that experienced significant in-migration of non-whites during World War II. The South shifted permanently to the Republicans at the presidential level in the 1960s with Nixon's veiled racist appeals. Those messages became more overt with Reagan and the first Bush, and explicit with Trump.

Congressional seats and state legislatures in the South shifted with a devil's bargain between the George H. W. Bush Administration and a few career African American southern politicians following the 1990 census. Until then the 1965 Voting Rights Act was understood to ban practices that diluted African American voting strength, including "packing" black voters into a few districts. The Bush Justice Department proffered a new interpretation: that African Americans could only have representation in Congress and state legislatures if they were represented by black politicians rather than officials of various races who owed their election to black voters. This interpretation was accepted by Federal judges, a majority of whom by then had been appointed by Republican presidents, and blacks were packed into a few districts. As a result, black voters who had provided the margins of victory for numerous white legislators throughout the South were concentrated in a few districts that then elected into safe Congressional seats the few African American state legislators who had endorsed this new interpretation of the Voting Rights Act. This was the turning point that sharply reduced Democrats in southern state legislatures and made possible the Republican takeover of the House in the 1994 election.

Republican control of the presidency, especially when combined with majorities in the Senate, has shifted the Federal judiciary to the right. Again leaving aside the policy effects, this matters politically because judges interpret laws and can strike down regulations. Right-wing Republican appointed judges have used their power to: (1) weaken union rights, undermining the most important left bloc in the US (as I discuss below), (2) allow unlimited campaign spending by the wealthy, which favors Republicans and gives Democrats an incentive to themselves move to the right to win over rich contributors, (3) allow corporate mergers, whose political consequences I discuss in the next section, and (4) approve Republican-initiated laws that make it harder for poor and non-white Americans to vote. (I return to this final consequence in the conclusion.)

\section{The structural bases of Democratic power}

The Democratic New Deal coalition was built upon an alliance of industrial workers, small farmers, and southern racists and sustained by capitalists whose 
interests were guarded by Federal regulatory mechanisms created under Roosevelt. The southern racist wing of the coalition was lost, as I discussed above, by Democrats' commitment to civil rights and by Republican success at making racist appeals that were veiled enough to hold northern suburban voters who would have been repelled by open racism and by isolating southern black voters.

Unions have been progressively weakened under Republican administrations from Eisenhower on. Indeed the brief term for Republican control over Congress in 1947-48 was important mainly for passage of the Taft-Hartley Act, which opened legal avenues to undermine unions and make it more difficult for unions to recruit new members. This was a very long-term project that only bore fruit in the 1970s. In 1954 a third of American workers belonged to unions; today it is under $10 \%$ and still dropping (Eidlin, forthcoming: table A1.1). Unions offer the only sustained supply of political workers for Democratic and are the largest source of campaign financing. The decline of unions has directly and decisively weakened Democrats, which provides a continuing incentive for Republican officeholders to enact laws and regulations that undermine union organizing.

The New Deal regulatory structure cleverly divided American capitalists. ${ }^{1}$ Competition was restricted by confining different sorts of firms to clearly defined national or local markets or to particular sectors. Banking especially was closely regulated. This had a number of political consequences, all of which bolstered liberal Democrats: First, firms needed help from members of Congress to navigate regulatory rulemaking, providing (as I noted above) a continuing reason for capitalists to offer campaign contributions to Congressional incumbents who until the 1990s were mainly Democrats. Second, firms that were confined within states by New Deal regulations depended for their continuing profitability on maintaining regulations that restricted the large national firms. These divisions among capitalists made it hard for them to mobilize the combined power to demand changes to the New Deal regulatory and social welfare architecture. The great exception to elite divisions was on the issue of labor unions, to which all capitalist were opposed even if some of the biggest firms were resigned to having to negotiate and share profits with their unionized workers. Thus, New Deal labor legislation was the first realm of regulatory retreat.

The New Deal system was gradually undermined when enforcement of antitrust legislation (which was far stronger than in Europe throughout the twentieth century) was fatally weakened when Nixon allowed almost every proposed merger. While Democrats were somewhat more restrictive than Republicans, antitrust enforcement was soft under Carter, Clinton and Obama. As national firms bought local ones, or local firms merged to become new national behemoths, divisions among capitalists were overcome and now unified sectors of capitalist joined to push for further deregulation of their industries, which in turn made further mergers possible. This process advanced most rapidly in banking, which culminated in the virtual elimination of regulation, making possible the sorts of 
fraud that culminated in the 2008 financial crisis. The other sector where deregulation advanced furthest was telecommunications, with political consequence I will discuss below.

\section{How the coarsening of the public sphere benefits Republicans}

Television stations, while mostly privately owned in the US, were highly regulated until the Reagan Administration when limits on the number of stations a single firm could own were relaxed. In addition, the Equal Time provision, which as the name suggests required stations to give equal time to both political parties and to advocates of opposing views, was eliminated. Public service requirements, which forced stations to devote several hours each day to news and educational programming, and which had to be of sufficient depth to meet that regulatory obligation, also were eliminated.

These deregulatory measures had two effects. First, most local stations, which became part of national firms and no longer were bound by the public service requirement, abandoned serious reporting about local and state politics and about the actions of members of Congress who, because they are elected locally, were reported on mainly by local television and newspaper reporters. This opened space for greater levels of corruption in government and for state legislators and members of Congress to take votes that favored corporate interests over the needs of ordinary constituents because those politicians could be confident that their malfeasance would not draw attention from the few remaining local reporters.

The end of the Equal Time provision allowed the emergence of ideologically biased networks, an opening that Rupert Murdoch and his key executive Roger Ailes used to create Fox News. The influence of Fox, the Sinclair TV and radio network, and rightwing radio "shock jocks" like Rush Limbaugh and his many imitators, has been massive. They became the primary news source for a majority of Republican primary voters, pushing the party further to the right, and creating a significant bloc of voters with a tenuous grasp on reality. Fox viewers believe, because that is what they hear on that network with no challenge from opposing speakers, that the US won the war in Iraq but then lost when Obama pulled out US troops, Obama is a Muslim, global warming is not real, and Hillary Clinton committed a number of crimes which Obama covered up for her. In addition, Fox News has pioneered an increasingly vulgar political discourse, one that Republican members of Congress mimic. The din of abusive and extreme rhetoric makes politics appear distasteful if not upsetting for a growing fraction of Americans, discouraging them from participation. Politics is further degraded by the successful Republican strategy of obstructing all initiatives by Democratic presidents. This has the real consequence of making it almost impossible for Democrats in office to deliver reforms and programs that their voters want, and thereby further discourages potential Democrats from voting.

The voters who were most discouraged in 2016 were the young and non-white, the groups that are most likely to vote Democratic. Beyond such 
disruptive tactics, Republicans seek to prevent potential Democrats from even having the right to vote. Republicans for years have made the false claim that many people vote illegally because they are not citizens. This has culminated in Trump's lie that he would have won the popular vote if noncitizens hadn't been allowed to vote for Clinton. Republicans have used that lie to impose ever-stricter laws requiring voters present proof of their identify and citizenship before being allowed to register and then vote in elections. Again, this has mainly affected the young and non-whites. These measures, which once were banned by the Voting Rights Act of 1965, now have been allowed by Republican judges who have reinterpreted the meaning of that Act. In 2013 the five Republican appointed Supreme Court justices struck down as unconstitutional the key provision of the Voting Rights Act, leading to a flood of voting restrictions in states controlled by Republicans.

\section{To the brink of victory}

All these structural changes and Republicans' smart strategic moves ensured that any Democratic presidential candidate would be at a disadvantage in 2016. That candidate would have his or her program measured in light of Obama's inability to fulfill many of his promises from eight years earlier. Democratic ideas would not be heard on Fox and would get little sustained coverage on the other networks, which have been able to abandon serious news reporting in the absence of public service requirements. Democratic voters would be discouraged, and many who still were eager to vote would not be able to register or would be turned away from voting on Election Day. Lax campaign finance laws, further gutted by the Supreme Court, allowed rich people to give unlimited funds to Republican organizations, allowing that party to overcome the usual advantage the Democrats should have had as the incumbent party. And unions would play a lesser role in 2016 than they had even in 2012 as their membership and treasuries continued to decline.

These structural imbalances were strengthened by Trump's shrewd and Hillary Clinton's stupid tactical decisions. Trump was able to win intense support from Evangelical Christians despite his debauched personal life and his continual lewd and blasphemous statements. He did so by picking Mike Pence as his Vice Presidential candidate and by releasing a list of potential Supreme Court nominees. Pence is rightly regarded as a stalwart conservative Christian committed to the positions of the most right-wing Evangelical ministers. The names on Trump's Supreme Court list were all on record as opposing abortion rights. Evangelicals have a long record of instrumental voting, showing a willingness to vote for (and attend churches led by) adulterers, crooks, and liars as long as they support conservative positions.

Trump positioned himself in opposition to some of the most hated policies of the past quarter century. His long-standing denunciations of trade treaties drew support from less educated workers whose well-paying factory jobs had moved abroad. The fact that Hillary Clinton's husband had been the president who passed and implemented NAFTA and that Hillary herself had been a powerful advocate 
for the Trans Pacific Partnership before she said she was opposed to it during her primary campaign against Bernie Sanders, made her the worst possible Democrat to challenge Trump on this issue. ${ }^{2}$

Trump falsely stated he had opposed the Iraq War from the beginning. However, few journalists called him on that lie and in any case Trump's assertion allowed him to present himself as an isolationist who would not send US troops to fight in foreign wars. Hillary Clinton, as a Senator and as Secretary of State, had positioned herself as a proponent of a militaristic foreign policy. She no doubt believed that such a stance was necessary for a woman who wanted to be president, but her image as a warmonger hurt her. Kriner and Shen (2017) "find that there is a significant and meaningful relationship between a community's rate of military sacrifice [in Afghanistan and Iraq] and its support for Trump. Our statistical model suggests that if three states key to Trump's victory - Pennsylvania, Michigan, and Wisconsin - had suffered even a modestly lower casualty rate, all three could have flipped from red to blue and sent Hillary Clinton to the White House".

Immigration proved to be a winning issue for Trump, as it has been for Brexit advocates and for extreme right politicians in much of Europe, even if they, unlike Trump, have failed to take national office. Racism, as I discussed above, has been a boon for Republicans for the past half century. It is unclear if Trump's overt racism won him more votes or merely made Republican racist voters more enthusiastic. Trump carried numerous counties that Obama had won in 2008 and 2012, which argues against race as a decisive factor. However, any one in the US who pays attention would observe widespread anger among racists at having to live under a black president, but again it is unclear how many of those were new Republican voters.

The decisive factor was that almost all Republicans stayed loyal to their party despite all their misgivings about Trump. There is clear evidence that adherents of the two parties are growing ever more distinct and express growing distrust and disgust at politicians from the other party. Marriage across party lines now is as rare as across class lines and half as unlikely as interracial marriages in the US (Huber and Malhotra, n.d.).

The Clinton campaign mistakenly thought that any votes it lost to Trump from former factory workers would be more than made up for with suburban Republican women disgusted by Trump. Democratic former Pennsylvania Governor Ed Rendell asserted:

Will [Trump] have some appeal to working-class Dems in Levittown or Bristol? Sure... For every one he'll lose 11/2, two Republican women. Trump's comments like "You can't be a 10 if you're flat-chested", that'll come back to haunt him. There are probably more ugly women in America than attractive women. People take that stuff personally. (Oh, 2016)

2 Karabel (2016) offers a clear analysis of how the Clinton and Obama presidencies and Hillary Clinton's own record undermined the chances of a Democratic victory in 2016.

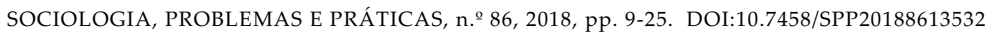


Rendell's thinking, which was echoed, albeit in more polite terms, by key Clinton campaign aides and by Hillary Clinton herself, led the Clinton team to focus their advertising and Clinton's campaign appearances in suburbs. She never once visited Wisconsin, assuming that a state Democrats had won in every presidential election since 1988 was safely in her column.

Faith in suburban women was only one of Hillary Clinton's many miscalculations. Allen and Parnes (2017) provide the most comprehensive account of Clinton's misplaced confidence and the deep stupidity of Robby Mook, her campaign manager. Yet many of the most serious mistakes were made before she began her presidential run. Her and her husband's strong and consistent support for trade agreements, noted above, were major liabilities in 2016. Her opposition to the Trans-Pacific Partnership after Sanders made it an issue, which she had called "the gold standard in trade agreements" (Carroll, 2015) when she was Secretary of State, made her appear to be dishonest and calculating.

Bill Clinton in 1992 and Hillary Clinton in 2008 had made barely veiled racist appeals in their respectively successful and failed campaigns for the Democratic nomination. Such racism was not enough to alienate the sort of older blacks who vote in Democratic primaries and who were unfamiliar and uncomfortable with Bernie Sanders. So while Sanders won a majority of white primary voters, Clinton's overwhelming support among blacks gave her the nomination. However, her racism didn't bring in white voters who preferred Trump, the real racist, but it did alienate enough younger black voters, who sat out the November election, to cost Clinton Wisconsin and Florida (Wilson, 2017).

Finally, both Clintons had enriched themselves giving speeches in the years after Bill left office. Most of the $\$ 100$ million+ they made came from speeches to corporations and trade groups. Even when it became clear that Hillary would run for the presidency in 2016 she continued her paid speechifying. She gave several speeches to Goldman Sachs, the firm most associated with the 2008 financial crisis and which has been described as "a great vampire squid wrapped around the face of humanity, relentlessly jamming its blood funnel into anything that smells like money" (Taibbi, 2010). While not illegal and not even clearly corrupt, the speeches certainly gave the impression that the Clintons had profited from office and were willing to peddle influence in her future presidency. That, and her unauthorized use of a private email server for official communication as Secretary of State, became the kernels of truth around which Trump built his reckless and sexist rhetoric about "crooked Hillary".

Trump's claims were reinforced by journalists who gave more attention to the email controversy than any other issue. The most comprehensive study finds that "between Oct. 15 and Election Day, roughly half (56\%) of the stories [on TV and in newspapers] about scandals and the economy mentioned Mrs. Clinton's emails, and only a quarter (26\%) discussed Mr. Trump and his imbroglios. A mere $7 \%$ of the stories in these last three weeks mentioned Mrs. Clinton and the economy $(11 \%$ mentioned Mr. Trump and the economy)" (Vavreck, 2016). The half hour evening news broadcasts of the three networks (CBS, NBC and ABC, but not including Fox) devoted 32 minutes to covering issues, 100 minutes to Clinton's emails, and 333 
minutes to Trump during the 2016 primary season alone (Boehlert, 2016). Such distorted coverage was possible only in the absence of equal time rules and was shaped in part by the years of relentless attacks on Clinton by Fox and Republican officeholders who together legitimized such biased and sensationalist reporting.

Despite the advantages the Republicans built for their presidential candidates over decades, Clinton still led Trump by a narrow though stable margin two weeks before Election Day. Then on October 28, eleven days before the election, FBI Director James Comey sent a letter to Congress announcing that he had received new information that might require reconsideration of his finding that Hillary Clinton had not violated the law when using her private email server. ${ }^{3}$ Such a letter was contrary to Justice Department protocols, which forbid any announcement in a politically sensitive case close to an election. While the FBI rapidly analyzed the new information and Comey was able to announce two days before the election that he could again clear Clinton of illegal activity, the damage was done. Estimates of the effect of the Comey letter range from 1 to 4 percentage points. Even the low end was enough to swing "Michigan, Pennsylvania, Wisconsin and Florida" to Trump, costing Clinton the election (Silver, 2017).

Finally, internal documents and emails from Clinton's campaign, her advisors, and the Democratic Party were hacked by Russian agents and given to WikiLeaks which then released excerpts that painted Clinton as a stooge of Goldman Sachs, her staff as incompetent manipulators, and the Democratic Party as biased in favor of Clinton and against Bernie Sanders. It is difficult to quantify the effect of Russia hacking and other forms of interference in the election, even if the extent of collusion between Russia and the Trump campaign eventually becomes clear.

We need to remember that despite all the obstacles Clinton won the popular vote by $2 \%$. Trump became president because the US still uses the electoral system developed 230 years ago and enshrined in the Constitution. The system was devised to ensure that southern slave states would dominate the presidency as they did: nine of the fifteen pre-Civil War presidents were from slave states, and they served forty-nine of the first seventy-two years of the Republic. Votes are awarded state by state, based on each state's number of Senators and Congressional Representatives, a system that now as then disproportionately favors small rural states. Most of the small states voted for Trump. That combined with Trump's very narrow margins in Wisconsin, Michigan and Pennsylvania put him over the top.

Comey was placed in a position to pass judgment on the legality of Hillary Clinton's private email server because in June 2016 Bill Clinton observed Attorney General Loretta Lynch's airplane on the tarmac in Phoenix near his plane. Clinton went on board to meet with Lynch right before she, as Attorney General, was going to announce that the Justice Department's investigation of the email server had found no illegality. Lynch's error in judgment in meeting with the husband of a person under investigation, even if he was a former president, created an uproar, of course stoked by Trump. Lynch was forced to announce she would leave the decision on whether to prosecute Hillary Clinton to Comey. 


\section{The Republican program and its prospects for success}

Trump made many (usually vague) promises and suggested even more during his long campaign. What will he actually do? We should base our predictions on the six factors that shape all administrations: (1) the interests of major campaign contributors, (2) the need to satisfy capitalists who have the ability to launch a capital strike and thus ruin the economy and end a president's chances for reelection (this almost always overlaps significantly with \#1), (3) the desires of key blocs of voters who are necessary to reelect the president and keep his party in power in Congress, (4) the need to win support in Congress for legislation and a budget to further the president's agenda, (5) the demands of the permanent military/foreign policy "deep state", and (6) the particular interests and proclivities of the president himself and his key advisors.

Under Trump, factors 1, 2 and 4 align closely.

Congressional Republicans led by House Speaker Paul Ryan are committed to a massive redistribution of income and wealth toward the top through tax cuts and by gutting major social programs. Indeed, Ryan gloated in March 2017, when it seemed certain that Medicaid would be cut massively, "We have been dreaming of this since I have been around, since you and I were drinking at a keg" (Tracy, 2017). This is the definition of a sociopath. Business overall favors such moves as well as advocating for deregulation, which most contributors and members of Congress also favor.

The easiest predictions are that Trump will eliminate environmental and financial regulations, freeing businesses and banks to merge, raise prices, pollute, and defraud their customers. Indeed, Scott Pruitt, Trump's Environmental Protection Administrator and his most capable appointee so far, has moved aggressively to cut back regulations. The only effective mode of opposition to deregulation will come through the courts. Rule changes require long processes and can be halted if plaintiffs can show the new regulations were formulated without evidence. However, past Republican presidents were able over time to reduce regulations on business and Trump's moves in that direction are nothing new. If Trump, so far, is less successful it is because his appointees are less competent than those of his Republican predecessors, and he has been so slow to even nominate people to fill the top posts in the cabinet departments.

The other area of continuity between Trump and past Republicans is in tax cuts heavily weighted toward the rich. His plan promises more than $47 \%$ of the income tax reductions to the top $1 \%$, similar to what Paul Ryan previously proposed. The estate and gift taxes, which are paid almost exclusively by the top $0.1 \%$, are slated to be totally abolished (Nunns et al., 2016). Senate budget rules will make it difficult to legislate permanent tax cuts, so Trump will have to follow George W. Bush's path of enacting tax cuts that expire after ten years (the limit under Senate rules). They would be extended only if Republicans control the presidency and Congress then. However, even if they expire, the tax cuts will produce ten years of fiscal crisis and budget cuts.

Trump's campaign promises to provide help for his more desperate working class supporters will not be enacted. He can assume most of those voters will stay 
loyal, if only because they applaud Trump's bigotry. Trump's contributors, business interests, and Congress all oppose new social programs. Thus, even though Trump, in an effort to burnish his daughter Ivanka's image, voiced support for a Federal childcare program no such legislation will be enacted. In any case, the actual plan his Administration outlined offers a tax credit that benefits only the wealthiest. Those earning under $\$ 40,000$ a year would get a benefit of $\$ 20$ annually from the Trump plan, and "more than $70 \%$ of the total tax benefits would go to families with income above $\$ 100,000$, and more than 25 percent to families with income above $\$ 200,000 "$. The plan is utterly inadequate to the scale of the need. "The president's child care proposals would cost about $\$ 115$ billion over ten years, about $2 \%$ of the total net cost of his campaign tax [cut] plan of about $\$ 6.1$ trillion over ten years" (Batchelder et al., 2017).

Beyond cuts in regulations and taxes for the rich, no other significant domestic initiatives will pass. Republican efforts under George W. Bush to privatize Social Security failed after the Senate voted unanimously against the plan, and there is no evidence that there wouldn't be overwhelming opposition to a renewed plan. Despite House Republicans' deep desire to privatize Medicare (the Federal medical program for the elderly) and limit Medicaid (the Federal medical program for the poor), both of which were enacted in 1965 under Lyndon Johnson, that too would be almost impossible to enact, in part because Medicare and Medicaid are vital to the profitability of hospitals, physicians, and pharmaceutical firms. Medicaid pays for a majority of nursing home care in the US.

Privatization would be not so much a transfer of the financial burden of medical care from government to patients as a decimation of the medical industry since the Federal government is, in essence, the payer of last resort for that sector of the economy because few elderly Americans could afford private insurance or to pay bills out of pocket. The existing universal social welfare programs, above all Social Security and Medicare, are widely popular, as are programs like Federally-subsidized student loans and mortgages, and also, it now appears, Obama's Affordable Care Act, even though it came into effect just in 2014.

\section{Trump and the World}

The US today pursues a geopolitical strategy that assumes continuing military supremacy and economic preeminence. Unlike the rethinking and restructuring that occurred under Nixon, Obama didn't attempt to recast America diplomacy or reduce its military stance. Trump, despite voicing criticisms of American failures in Libya, Iraq, and elsewhere, albeit in isolationist rather than anti-imperialist terms (Parenti, 2016), has assembled a national security team led entirely by retired and serving generals. Trump's ignorance, inexperience and laziness, and the cluelessness of his Secretary of State, former Exxon CEO Rex Tillerson, ensure that the shadow diplomatic corps created by the military through its regional commands around the globe will become even more the source of American foreign policy. 
Reassurance for allies, in the early months of the Trump Administration, has come from the Secretary of Defense and the National Security Advisor (the former a retired, and the latter an actively serving, general) rather than from the diplomatic corps or from White House officials. Trump's announcement of a $\$ 110$ billon arms sale to Saudi Arabia during his visit to that monarchy in May 2017, merely continues America's longstanding policy of cementing links with dictatorships through military ties as well as Obama's own $\$ 115$ billion of arms sales to the Saudis during his two terms. Indeed many of the sales Trump announced actually were negotiated under Obama (Landler, Schmitt and Apuzzo, 2017), and others, as in deals announced during previous Administrations, may never occur. Those sales, while always announced by civilian officials, are in substance negotiated by US generals with their foreign counterparts.

Trump's withdrawal from the Trans-Pacific Partnership in the first week of his presidency matters less for the TPP itself, which was unlikely to be ratified by the US Senate even if Hillary Clinton had become president, than as a signal to other nations that the US no longer is willing to negotiate or even maintain treaties that open some American markets to foreign competitors in return for other nations' participation in a global trade regime designed by the US. In essence, the US government now appears before the world as seemingly unable to muster the domestic political consent to spend the resources needed to sustain its economic hegemony. Of course, the costs of that hegemony have been borne by industrial workers rather than directly in the state budget. However, in the past, elites came together and were able to suppress popular resistance to enact a series of treaties and to empower international bodies that built and maintained, through decades of crises, the US-led trade and financial system.

Trade politics in the US is likely to remain stalemated at least through Trump's presidency. Business interests will block him from withdrawing from existing trade agreements or from negotiating anything more than minor superficial changes. At the same time, Trump's election demonstrated conclusively the depth of opposition among American voters to further trade liberalization. The US will not be party to any more major agreements. Trump's efforts to play to his core supporters with denunciations of trade pacts and his Muslim ban and other crackdowns on immigration will cause firms to invest less in the US and reorganize their production chains to avoid the US as much as possible. Immigrants and refugees will be excluded and undocumented residents will live in fear and some will be deported, although again Trump's incompetence will limit that.

Even if Trump were to leave office tomorrow, the US will remain the country whose electorate made a man like Trump president, and earlier elected and reelected George W. Bush. If voters didn't learn (or only learned for two election cycles) the lessons of the Bush Administration, there is no guarantee that any lessons from the Trump years will have a lasting influence on US politics. A future US president could be just as, or even more (if that is possible), unstable and reactionary. Any rational government in the world (and almost all governments, at least those with substantial economies and militaries, are rational) now will try to reorder its affairs so that it is less dependent on the US for military and diplomatic protection 
and for economic growth. German Chancellor Angela Merkel publically and explicitly made this point after her first official meeting with Trump in May 2017.

The reordering of global alliances is being manifested in concrete actions during the first months of the Trump Administration. The China-led Regional Comprehensive Economic Partnership is moving toward a final agreement in the wake of the demise of the TPP. This new association, like TPP, would do little to deepen and accelerate the already dense trade links among the signatories. Rather the RCEP would be the first step in moving China to a central position in the regulation of global trade and finance. At the same time, China's huge investments in infrastructure in southeast and south Asia and in the Middle East through the "One Belt, One Road" scheme could lock in the economies and trade networks of countries throughout Eurasia with China, permanently disadvantaging the US and impelling the EU to at least in part shift its focus from North America to China.

Trump's withdrawal from the Paris climate accord in June 2017, joining only Syria and Nicaragua, has led other countries to reaffirm their commitment to the Paris process. Indeed, Trump's ability to increase fossil fuel use in the US remains dependent on favorable court decisions and will be countered by various states' and cities' increasing regulation of energy production and use. It is, as yet, unclear if America's withdrawal will lead other countries to pull back on or intensify their programs to cut $\mathrm{CO} 2$ emissions or if some countries will combine to impose transnational carbon taxes that would disadvantage American exports, putting further pressure on the US to return to the fold, albeit after ceding (thanks to Trump and the Republicans in Congress) diplomatic and technological leadership to China and the EU.

The Afghan and Iraq wars, which were greatly deescalated under Obama, became sites of reescalation toward the end of Obama's second term and now the generals are asking a compliant Trump to authorize further troop supplements in those two countries and Syria as well. While Trump himself is ignorant, easily provoked, and incapable of engaging in serious negotiations even as he undercuts his Secretary of State, the real military decisions will remain in the hands of the generals who like to buy and play with high-tech weapons but have no interest in fighting real wars that they could lose.

\section{What might derail Trump and the Republicans?}

Six and eight months in, Trump suffered major defeats when Senate Republicans were unable to muster the fifty votes needed to pass a repeal of Obamacare. This had been the leading issue for Congressional Republicans for the past seven years. Enough Republican senators responded to mass pressure from their constituents, especially those in rural states, who learned that they in fact were beneficiaries of Obamacare. Amusingly, more than a few voters did not know that the Affordable Care Act, the official name of the program that provided them with subsidized health insurance, was the same as Obamacare. Once they became aware of that fact, they demanded the program be preserved. However, these mass protests did not 
on their own persuade enough senators to oppose repeal of Obamacare, the coup de grace came from the owners and managers of insurance companies, nursing homes, hospitals, and medical supply companies that profit from Obamacare and pressured senators from rural states to block the repeal.

Ad hoc alliances between mass movements and business interests seem likely to limit Trump's ability to severely limit immigration and to expel undocumented immigrants. Trump's inability or unwillingness to fill a majority of the top positions in his administration and the incompetence of many of those he has installed will limit his Administration's ability to navigate the complex paths needed to rewrite or repeal regulations instituted by Obama and earlier Democratic presidents.

The US political system maintains numerous "veto points". Those who oppose changes in Federal regulations can sue in court to block or delay the changes. Members of Congress represent local and state constituencies that have particular interests in maintaining government social welfare and other programs and will be able to apply leverage to force Congress as a whole to continue spending. Trump's effort to end funding for the arts, for example, was immediate rejected by Congress and that will be the case for many of his budgetary proposals.

There are three great unknowns that each could weaken or strengthen Trump and the Republicans: war, the economy and scandal. While career generals will continue to dominate American foreign policy, Trump can't be totally sidelined and it is possible he will do something that could spark a war. Past wars always have created an initial rush of support for the incumbent president, and so a new war would strength Trump politically. However, Americans are very impatient for rapid success, and are especially so when the reasons for the war are revealed to be bogus, as they were in Iraq. Thus, failure to win a quick victory would turn war into a liability for Trump. However, timing is everything. Bush began the Iraq war close enough to the November 2004 election that the public's turn against the war came just too late to prevent his reelection.

Bartels' (2008) analysis of the relation between the economy and election results make clear that voters focus on the incumbent party's economic record in the year before a presidential election rather than over the whole four-year term. So the timing of the next recession will be critical. If the economy under Trump follows the Reagan or G. W. Bush pattern with slow growth and the absence of recession (or with a recovery from a recession early in Trump's presidency) voters will think it is Morning in America again and a majority will view his policies as a success even though job growth will be slower than under earlier Democratic administrations and inequality deepens. Alternately, any or all of a crash of market bubbles, trade wars, and inflation could create clear declines in incomes for a majority of voters who then punish Trump and Congressional Republicans in 2018 or 2020.

Finally, the dimensions of Trump's collusion with Russia remain unclear, although Trump, his family and staff give every indication that they are terrified of what might be revealed and are doing everything they can to suppress the ongoing investigations. Congressional Republicans show no sign that they will move against Trump if he were to fire Robert Mueller, the special counsel (a move that 
would echo Nixon's effort derail the Watergate investigation with his Saturday Night Massacre in 1973), or use his constitutional authority to pardon his family, campaign staff or himself. The extent of the public reaction to such criminal behavior is unknown, and how it would combine with or counteract other electoral forces to shape the Congressional and next presidential elections is unknowable at this point.

Republicans certainly will continue their long-term and deepening efforts to suppress Democratic voters in an attempt to ensure that the electorate is small enough to maintain their continuance on power. Tactics such as reducing the number of polling places and the hours they are open (which disproportionately discourage poor and urban voters) and above all imposing more onerous requirements that voters show identification proving their citizenship (which also target poorer people who are less likely to have the needed documents available) have worked in the past to reduce the number of voters. As discussed above, this is one more area where Republican-appointed judges show political bias, allowing such tactics that in the past judges almost unanimously found were discriminatory and therefore unconstitutional.

Trump's unpopularity and the public's clear rejection of almost all the policies Republicans seek to enact would, in normal times, ensure a decisive shift toward Democrats in the next elections. However, twenty-first century Republicans have not been willing to work within the American legal and constitutional limits and are not constrained by customary democratic norms. It is not at all certain that existing institutional forces are strong enough to constrain this assault on democracy. Those of us in the US who oppose Trump could find ourselves in a situation analogous to that of liberal white South Africans under apartheid: free to speak against the regime, able to enjoy a high standard of living in culturally vibrant enclaves, but having to wait and hope for outside forces sufficiently powerful to topple an authoritarian regime.

\section{References}

Allen, Jonathan, and Amie Parnes (2017), Shattered. Inside Hillary Clinton's Doomed Campaign, New York, Crown.

Bartels, Larry (2008), Unequal Democracy. The Political Economy of the New Gilded Age, Princeton, Princeton University Press.

Batchelder, Lily, Elaine Maag, Chye-Ching Huang, and Emily Horton (2017), “Who benefits from Preisdetn Trump's child care propsoals?", Tax Policy Center, February 28, available at: https://www.taxpolicycenter.org/sites/default/files/publication/138781/2001170 -who-benefits-from-president-trumps-child-care-proposals.pdf (last access July 21, 2017).

Boehlert, Eric (2016), "Study confirms network evening newscasts have abandoned policy coverage for 2016 campaign", Media Matters, October 26, available at: https://www.mediamatters.org/blog/2016/10/26/study-confirms-network-evening-n ewscasts-have-abandoned-policy-coverage-2016-campaign/214120 (last access July $16,2017)$. 
Carroll, Lauren (2015), “What Hillary Clinton really said about TPP and the 'gold standard' ", PoltiFact, October 13, available at: http://www.politifact.com/truth-o-meter/statements/2015/oct/13/hillary-clinton/wh at-hillary-clinton-really-said-about-tpp-and-gol/ (last access July 18, 2017).

Eidlin, Barry (forthcoming), Labor and the Class Idea in the U.S. and Canada, Cambridge, Cambridge University Press.

Hooks, Gregory, and Brian McQueen (2010), "American exceptionalism revisited: the military-industrial complex, racial tension, and the underdeveloped Welfare State", American Sociological Review, 75, pp. 185-204.

Huber, Gregory, and Neil Malhotra (n.d.), "Political homophily in social relationships: evidence from online dating behavior", unpublished paper available at: http://huber.research.yale.edu/materials/38_paper.pdf (last access July 15, 2017).

Karabel, Jerome (2016), "The roots of the democratic debacle", Huffington Post, December 12, available at: http://www.huffingtonpost.com/entry/the-roots-of-the-democratic-debacle_us_584 ec983e4b04c8e2bb0a779? (last access July 21, 2017).

Kriner, Douglas L., and Francis X. Shen (2017), "Battlefield casualties and ballot box defeat: did the Bush-Obama wars cost Clinton the White House?", available at SSRN (June 19): https://ssrn.com/abstract=2989040.

Lachmann, Richard (2014), "From consensus to paralysis in the United States, 1960-2012", Political Power and Social Theory, 26, pp. 195-233.

Landler, Mark, Eric Schmitt, and Matt Appuzo (2017), “\$110 billion weapons sale to saudis has jared Kushner's personal touch", The New York Times, May 18, available at: https://www.nytimes.com/2017/05/18/world/middleeast/jared-kushner-saudi-arabi a-arms-deal-lockheed.html?_r=0 (last access July 18, 2017).

Nunns, James, Leonard Burman, Jeffrey Rohaly, and Joseph Rosenberg (2016), An Analysis of Donald Trump's Revised Tax Plan, Washington, DC, Tax Policy Center, available at: http://www.taxpolicycenter.org/publications/ analysis-donald-trumps-revised-tax-plan/full (last access July 18, 2017).

Oh, Inae (2016), “Ed Rendell has some thoughts on why Hillary Clinton will defeat Donald Trump", Mother Jones, May 18, available at: http://www.motherjones.com/politics/2016/05/ed-rendell-hillary-clinton-ugly-wom en-trump/ (last access July 15, 2017).

Parenti, Christian (2016), "Listening to Trump", Nonsite.org, November 17, available at: http://nonsite.org/editorial/listening-to-trump (last access July 16, 2017).

Silver, Nate (2017), "The Comey letter probably cost Clinton the election", FiveThirtyEight, May 3, available at: https:/fivethirtyeight.com/features/ the-comey-letter-probably-cost-clinton-the-election/ (last access July 16, 2017).

Taibbi, Matt (2010), “The great American bubble machine", Rolling Stone, April 5, available at: http://www.rollingstone.com/politics/news/the-great-americanbubble-machine-20100405 (last access July 15, 2017).

Tracy, Abigail (2017), “Paul Ryan says he has been 'dreaming' of cutting medicaid since he was in college", Vanity Fair, March 17, available at: http://www.vanityfair.com/news/2017/03/paul-ryan-medicaid (last access July 21, 2017). 
Vavreck, Linda (2016), "Why this election was not about the issues", The New York Times, November 23, available at:

https:/www.nytimes.com/2016/11/23/upshot/this-election-was-not-about-the-issue s-blame-the-candidates.html?_r=0 (last access July 16, 2017).

Wilson, Reid (2017), “Voter turnout dipped in 2016, led by decline among blacks", The Hill, May 11, available at:

http://thehill.com/homenews/campaign/332970-voter-turnout-dipped-in-2016-ledby-decline-among-blacks (last access July 15, 2017).

Richard Lachmann. Professor at State University of New York at Albany, College of Arts and Sciences, Sociology Department, 1400 Washington Ave, Arts \& Sciences, 351, Albany, New York 12222. E-mail: rlachmann@albany.edu

Receção: 24 de março de 2017 Aprovação: 05 de junho de 2017 